\title{
KINERJA PERAWAT DALAM MELAKUKAN PENGKAJIAN TERHADAP PASIEN DI DALAM ASUHAN KEPERAWATAN
}

\section{SELLY FEBI MARGARETHA PANGGABEAN}

$\underline{\text { sellyfebi2601@gmail.com }}$

\section{LATAR BELAKANG}

Perawat merupakan profesi yang memberikan pelayanan keperawatan kepada pasien, dimana salah satu aspek terpenting dari kinerjanya adalah pengkajian asuhan keperawatan. Kinerja perawat dalam pelayanan keperawatan dipengaruhi oleh beberapa faktor yaitu karateristik organisasi (kepemimpinan), karateristik individu (motivasi), dan karateristik pekerjaan (beban kerja). (Nursalam, 2015). Pengkajian adalah tahap awal dan dasar dalam asuhan keperawatan yang paling menentukan bagi tahap berikutnya.

Dalam melakukan pengkajian, seorang perawat harus mampu melakukan pengumpulan data yang akurat dari pasien atau para narasumber lainnya agar dapat menentukan diagnosa keperawatan, mengidentifikasi kebutuhan unik pasien terhadap masalah keperawatan,serta menjamin adanya informasi dasar yang berguna supaya dapat memberikan referensi untuk mengukur perubahan kondisi pasien. Oleh karena itu, proses pengkajian harus dilakukan dengan teliti,bijaksana dan cermat, sehingga seluruh kebutuhan perawatan pada pasien dapat di identifikasi dan digunakan untuk menghimpun atau mendapatkan informasi tentang status kesehatan pasien, meliputi dari aspek biologis, psikologis, social maupun spiritual.

Pengkajian yang komprehensif atau menyeluruh, sistematis yang logis akan mengarah dan mendukung pada identifikasi masalah- masalah pasien. Masalah - masalah ini dengan menggunakan data pengkajian sebagai dasar formulasi yang dinyatakan sebagai diagnosa keperawatan. Maka, data yang didapati dari hasil pengkajian, akan menentukan keberhasilan seorang perawat dalam kinerja atau kemamapuan dalam mengidentifikasi permasalahan pasien ditahap berikutnya. Oleh karena itu, peran seorang perawat sangat penting dalam pelaksanaan 
proses pengkajian, guna menghasilkan kinerja yang berkualitas dan kuantitas yang dicapai dalam melaksanakan tugas dan tanggung jawab yang diberikan kepadanya. Kinerja perawat bukan sekedar dinilai dari kesediaan tenaga keperawatan ataupun tugas, tetapi lebih dari itu. Kinerja tersebut, harus memperhatikan juga mengenai kesediaan individu melakukan tindakan (Bakri,2017).

\section{METODE}

Dalam kajian ini, metode yang digunakan adalah Literature review dari sumber bacaan seperti jurnal online, textbook, e-book, dengan cara membaca, menganalisis, dan melakukan perbandingan jurnal kajian dengan pokok bahasan kajian tentang kinerja perawat dalam melakukan pengkajian terhadap pasien dalam asuhan keperawatan.

\section{HASIL}

Dari hasil Jurnal 'Aisyiyah Medika Vol. 4, Nomor 2 . Menurut hasil dari jurnal tersebut menyimpulkan bahwa kinerja perawat dalam melakukan pengkajian sampai pendokumentasian, dalam asuhan keperawatan, diketahui bahwa lebih dari setengah responden seorang perawat, memiliki kinerja asuhan keperawatan yang kurang baik, yaitu sebanyak 75\%. Sedangkan responden perawat yang memiliki kinerja asuhan keperawatan dalam kategori baik, sebanyak $25 \%$.

Dari hasil Jurnal Keperawatan Muhammadiyah 1(1). Menurut hasil jurnal tersebut menyimpulkan bahwa kinerja perawat dalam melakukan pengkajian asuhan keperawatan berbasis komputer berdasarkan karateristik responden, bahwa kategori kinerja perawat yang melakukan pengkajian dengan baik lebih banyak dibandingkan kategori kinerja perawat yang kurang baik dalam melakukan pengkajian dalam asuhan keperawatan.

Maka hasil dari perbandingan kedua jurnal tersebut, sama - sama menyimpulkan bahwa kinerja perawat dalam melakukan pengkajian asuhan keperawatan lebih banyak mengarah kepada kategori kinerja perawat yang baik dalam melakukan pengkajian asuhan keperawatan, 
daripada kategori kinerja perawat yang kurang baik dalam melakukan pengkajian asuhan keperawatan. Oleh karena itu, seorang perawat harus lebih meningkatkan kinerja atau usahanya yang lebih baik lagi dalam melakukan segala tindakan asuhan keperawatan baik dalam pengkajian, tindakan, dan pendokumentasian yang akan dilakukan terhadap klien ataupun pasien kedepannya, dengan begitu peran penting perawat saat menghadapi pasien dirumah sakit ialah harus mengutamakan kinerja yang baik dan profesional secara keseluruhan untuk melakukan tindakan asuhan keperawatan.

\section{PEMBAHASAN}

Kinerja merupakan hasil dari suatu tindakan atau pelaksanaan tugas dari seseorang pada suatu organisasi dalam periode waktu tertentu, dimana untuk dapat menghasilkan kinerja yang baik seseorang memiliki kemampuan, kemauan, usaha serta dukungan dari lingkungan.

Menurut Prawirosentono, kinerja atau performance adalah usaha yang dilakukan dari hasil kerja yang dapat dicapai oleh seseorang atau sekelompok orang dalam suatu organisasi sesuai dengan wewenang dan tanggung jawab masing-masing dalam rangka mencapai tujuan organisasi bersangkutan secara legal, tidak melanggar hukum dan sesuai dengan moral maupun etika (Usman,2011).

Perawat sebagai salah satu tenaga kesehatan di rumah sakit memegang peranan penting dalam upaya mencapai tujuan pembangunan kesehatan. Keberhasilan pelayanan kesehatan bergantung pada partisipasi perawat dalam memberikan asuhan keperawatan yang berkualitas bagi pasien (Potter \& Perry, 2005). Dengan ini, peranan penting dari seorang perawat salah satunya adalah mampu melakukan pengkajian. Pengkajian yang maksud adalah pemikiran dasar dari proses keperawatan yang bertujuan untuk mengumpulkan informasi atau data tentang pasien, agar dapat mengidentifikasi, mengenali masalah-masalah, kebutuhan kesehatan dan keperawatan pasien, baik fisik, mental, sosial dan lingkungan. Data yang didapat dari hasil pengkajian, akan menentukan keberhasilan dari hasil kinerja perawat di dalam mengindentifikasikan permasalahan pasien di tahap berikutnya.

Berdasarkan wawancara yang terdapat dalam jurnal, ada beberapa tujuan yang harus dilakukan seorang perawat dalam melakukan pengkajian pengumpulan data asuhan keperawatan, yaitu :

1. Mengumpulkan informasi terkait status kesehatan klien dari berbagai sumber data 
2. Mengumpulkan, mengorganisasikan, serta mencatat berbagai data yang menjelaskan respon tubuh akibat masalah kesehatan

3. Mengidentifikasikan kebutuhan unik pasien terhadap masalah keperawatan yang akan memengaruhi layanan keperawatan yang diberikan.

4. Mengumpulkan data fokus yang mendukung masalah keperawatan yang sedang atau akan dihadapi klien.

5. Menjamin adanya informasi dasar yang berguna supaya dapat memberikan referensi untuk mengukur perubahan kondisi pasien.

6. Menyajikan data yang cukup bagi justifikasi kebutuhan paien untuk melakukan tindakan keperawatan

Dalam melakukan pengkajian yang terutama yang dilakukan oleh seorang perawat adalah dengan mengetahui teknik atau cara dari pengumpulan data. Beberapa tahapan teknik dalam pengumpulan data, yaitu :

1. Anamnesis : Cara pemeriksaan yang dilakukan dengan wawancara yang baik, langsung kepada pasien maupun keluarga pasien. Teknik ini membantu menegakkan diagnosa sementara.

2. Observasi : Kegiatan mengamati perilaku dan keadaan klien untuk memperoleh data tentang masalah kesehatan klien. Observasi memerlukan keterampilan disiplin dan praktik klinik sebagai bagian dari tugas perawat. Contoh kegiatan dalam observasi, yaitu: terlihat adanya kelainan fisik, adanya perdarahan, ada bagian tubuh yang terbakar, bau alkohol, urin, feses, tekanan darah, heart rate, batuk menangis, dan ekspresi nyeri.

3. Pemeriksaan Fisik : Menentukan respon pasien terhadap penyakit / berfokus pada respon yang ditimbulkan pasien akibat masalah kesehatan yang sudah di diagnosis oleh dokter. Pemeriksaan fisik yang harus dilakukan adalah dengan menggunakan teknik Physical Examination yaitu : Inspeksi (observasi /melihat), Palpasi (meraba), Perkusi (mengetuk), Auskultasi (mendengarkan suara didalam tubuh pasien).

Dalam proses melakukan pengkajian pengumpulan data tersebut, biasanya seorang perawat yang sedang melakukan pengkajian selalu ada hambatan yang akan dihadapi, seperti tidak mendapatkan data pasien yang akurat, tidak mampu melakukan pemeriksaan fisik dengan baik, dan juga sering mendapatkan kesulitan dalam berkomunikasi atau respon feedback yang tidak baik antara perawat dan pasien. 
Faktor penghambat pelaksanaan dalam melakukan pengkajian asuhan keperawatan, meskipun pada dasarnya proses keperawatan telah diterapkan. Berdasarkan hasil literature review yang telah di simpulkan, ada berbagai hambatan - hambatan yang terjadi pada saat pelaksanaan asuhan keperawatan, seperti :

1. Kurangnya pemahaman dasar-dasar pengkajian sampai pendokumentasian keperawatan. Hal ini bisa terjadi karena latar belakang pendidikan yang berbeda-beda, sehingga tidak adanya keseragaman pelaksanaan dokumentasi keperawatan.

2. Kurangnya kesadaran akan pentingnya pengkajian dan pendokumentasian keperawatan. Penulisan dokumentasi keperawatan tidak mengacu pada standar yang sudah ditetapkan, sehingga terkadang tidak lengkap dan akurat.

3. Banyaknya lembar format yang harus diisi untuk mencatat data dan intervensi keperawatan pada pasien membuat perawat terbebani

4. Keterbatasan tenaga. Kurangnya tenaga perawat yang ada dalam suatu tatanan pelayanan kesehatan memungkinkan perawat bekerja hanya berorientasi pada tindakan saja. Tidak cukup waktu untuk menuliskan setiap tindakan yang telah diberikan pada lembar format pengkajian keperawatan

5. Ketiadaan penggandaan lembar format pengkajian keperawatan oleh institusi

Jika seorang perawat memiliki cara untuk menyelesaikan faktor penghamat dengan menggunakan komponen kemampuan, kemauan dan usaha, maka faktor penghambat yang akan dihadapi perawat akan mudah terselesaikan, jika perawat memiliki komponen tersebut, maka kinerja seorang perawat dikatakan sudah berhasil dalam melakukan tindakan pelaksanaan asuhan keperawatan kepada pasien.

Perawat mempunyai konsep etika keperawatan, hak peran dan fungsi dari perawat yang wajib dilaksanakan dalam memberikan pelayanan kesehatan. Bila hal ini dikaitkan dengan integritas maka setiap tindakan pelayanan keperawatan dilaksanakan sesuai dengan etika dan fungsi perawat kepada pasien. Perawat yang mempunyai integritas yang baik maka akan menghasilkan pelayanan yang berkualitas yang mencerminkan dari kinerja keperawatan yang baik. Sehingga integritas menjadi salah satu komponen yang penting dalam menentukan kinerja seseorang dengan melihat hasil dari tindakan pelayanan yang diberikan. 


\section{PENUTUP}

Kinerja merupakan hasil dari suatu tindakan atau pelaksanaan tugas dari seseorang pada suatu organisasi dalam periode waktu tertentu, dimana untuk dapat menghasilkan kinerja yang baik seseorang memiliki kemampuan, kemauan, usaha serta dukungan dari lingkungan. Kinerja perawat merupakan ukuran keberhasilan dalam mencapai tujuan pelayanan keperawatan. Kinerja perawat dinilai dari kepuasan pasien. Perawat harus meningkatkan kinerjanya dalam melakukan kemampuan dan keterampilan dalam melakukan tugasnya, baik dalam pengkajian, pengumpulan data, tindakan sampai ke pendokumentasian. Oleh karena itu, peran perawat sangat penting dalam melakukan keseluruhan tindakan pelaksanaan baik kepada pasien ,individu, organisasi, kelompok, serta institusi dan peran penting perawat yang harus ditingkatkan adalah harus mengutamakan kinerja yang baik dan profesional secara keseluruhan untuk melakukan tindakan asuhan keperawatan.

\section{DAFTAR PUSTAKA}

Aris Citra Wisuda, Dwi Octhaviana Putri. (2019) Kinerja Perawat Pelaksana Dalam Pendokumentasian Asuhan Keperawatan Di Instalasi Rawat Inap. Jurnal 'Aisyiyah Medika. Volume 4, Nomor 2

Kumajas, F. (2012). Hubungan karakteristik individu dengan kinerja perawat di ruang rawat inap penyakit dalam rsud datoe binagkang kabupaten bolaang mongondow. Jurnal PSIK FK Universitas Sam Ratulangi.

Miming Oxyandi, Suherwin. (2018). Analisis Kinerja Perawat Pelaksana Dalam Pemberian Asuhan Keperawatan Di Instalasi Rawat Inap Tahun 2018. Jurnal 'Aisyiyah Medika. Volume 2, Agustus 2018

Mulyono, M.Hadi. Faktor Yang Berpengaruh Terhadap Kinerja Perawat Di Rumah Sakit Tingkat III Ambon. Jurnal AKK, Vol 2 No 1, Januari 2013, hal 18-26.

Noorkasiani, R Gustina, Siti Maryam. (2015). Faktor- Faktor yang Berhubungan dengan Kelengkapan Dokumentasi Keperawatan. Jurnal Keperawatan Indonesia, 1, 1-8. 
Nursalam. (2014). Manajemen Keperawatan. Aplikasi dalam Praktik Keperawatan Profesional. Jakarta: Penerbit Salemba Medika.

Pratiwi PP, Suryani M, Sayono. (2015). Hubungan Tingkat Pendidikan dan Lama Kerja dengan Kelengkapan Pengisian Dokumentasi Pengkajian Asuhan Keperawatan di RSUD Tugurejo Semarang. Program Studi S1 Keperawatan STIKES Telogorejo.

Pramithasari, I. D. (2016). Gambaran Kinerja Perawat Dalam Mendokumentasikan Asuhan Keperawatan Berbasis Komputer Di RSUD Banyumas. Jurnal Keperawatan Muhammadiyah, 1 (1) : $40-45$

Simamora, R. H. (2019). Development of Guidelines for Applying appropriate Patient Identification to Achieve Patient Safety Goal INC2019 12th International Nursing Conference. 2019.10455 - 455 (1 pages) UCI(KEPA) : I410-ECN-0101-2019-512-001224337

Simamora. R. H. (2008) The correlation of ward chief's giving direction and command and the performance of on-duty nurses at Jember dr. Subandi general hospital inpatient wards. jurnal Administrasi dan Kebijakan Kesehatan, (https://fkm.unair.ac.id/jurnal-administr) 